Article

\title{
Chemical Composition and Antioxidant Activity of the Main Fruits Consumed in the Western Coastal Region of Ecuador as a Source of Health-Promoting Compounds
}

\author{
Mabel Guevara ${ }^{1}$, Eduardo Tejera ${ }^{2}$, María G. Granda-Albuja ${ }^{2}$, Gabriel Iturralde ${ }^{3}$, \\ Maribel Chisaguano-Tonato ${ }^{4}$, Silvana Granda-Albuja ${ }^{5}$, Tatiana Jaramillo-Vivanco ${ }^{6}$, \\ Francesca Giampieri ${ }^{7,8}\left(\mathbb{D}\right.$, Maurizio Battino ${ }^{7,8,9, *(\mathbb{D})}$ and José M. Alvarez-Suarez ${ }^{1, *(\mathbb{D})}$ \\ 1 Facultad de Ingeniería y Ciencias Aplicadas, Grupo de Investigación en Biotecnología Aplicada a \\ Biomedicina, Universidad de Las Américas, Av. de los Granados E12-41y Colimes esq., \\ EC170125 Quito, Ecuador \\ 2 Facultad de Ingeniería y Ciencias Aplicadas, Grupo de Bio-Químioinformática, Universidad de Las \\ Américas, Av. de los Granados E12-41y Colimes esq., EC170125 Quito, Ecuador \\ 3 Laboratorios de Investigación, Universidad de Las Américas, Av. de los Granados E12-41y Colimes esq., \\ EC170125 Quito, Ecuador \\ 4 Nutrición, Escuela de Salud Pública, Facultad de Ciencias de la Salud, Universidad San Francisco de Quito, \\ Campus Cumbayá, Diego de Robles s/n, 170901 Quito, Ecuador \\ 5 Departamento de Biotecnología, Universidad de Las Fuerzas Armadas, Túnel Principal Universidad de las \\ Fuerzas Armadas-ESPE, 171103 Sangolquí, Ecuador \\ 6 Jardín Botánico de Quito, Quito, Interior Parque Carolina, 170135 Quito, Ecuador \\ 7 Nutrition and Food Science Group, Department of Analytical and Food Chemistry, CITACA, CACTI, \\ University of Vigo-Vigo Campus, 36310 Vigo, Spain \\ 8 Department of Clinical and Molecular Sciences, Faculty of Medicine, Polytechnic University of Marche, \\ Via Pietro Ranieri, 60131 Ancona, Italy \\ 9 International Research Center for Food Nutrition and Safety, School of Food and Biological Engineering, \\ Jiangsu University, Zhenjiang 212013, China \\ * Correspondence: maurizio.battino@uvigo.es (M.B.); jose.alvarez@udla.edu.ec (J.M.A.-S.); \\ Tel.: +39-071-2204646 (M.B.); +593-(2)-3981000 (ext. 7500) (J.M.A.-S.)
}

Received: 3 July 2019; Accepted: 1 September 2019; Published: 10 September 2019

\begin{abstract}
We studied 19 different tropical fruits traditionally consumed in the coastal lowlands of Ecuador to determine their chemical composition and antioxidant activity. Carambola (Averrhoa carambola L.) had the highest total phenolic, flavonoid, and total antioxidant capacity values, whereas guava fruits (Psidium guajava L.) had the highest vitamin C values. The main organic acids identified were lactic, citric, and acetic acids, and the highest amount of lactic acid was found in soursop fruits (Annona muricata L.), whereas Ecuadorian ivory palm (Phytelephas aequatorialis Spruce) and guava fruits had the highest acetic acid content. Guava also had the highest citric acid content; the highest concentration of oxalic acid was found in carambola. In terms of sugar content, giant granadilla (Passiflora quadrangularis L.) had the highest values of glucose, and red mombin (Spondias mombin L.) had the largest values for fructose and guava for sucrose. Chili pepper (Capsicum chinense Jacq) proved to be the main source of carotenoids, lutein, and $\beta$-carotene, anthocyanins, and vitamin $C$. The results here increase our knowledge regarding the composition of the main fruits consumed on the west coast of Ecuador to facilitate recommendations as potential sources of health-promoting compounds.
\end{abstract}

Keywords: tropical fruits; nutraceuticals; antioxidant capacity; bioactive compounds; Ecuador 


\section{Introduction}

The considerable biodiversity found in the South American biomes, such as in Ecuador's Andean, coastal, and Amazon forest regions, represents a poorly studied source of new plants for human nutrition. Ecuador is one of the most mega-diverse countries in the world, with a natural wealth that distinguishes it from the rest of the Andean countries. The country boasts a large number of fruit specimens, some native to Ecuadorian biomes, with others introduced to the country. These specimens were domesticated by the indigenous native populations over the years, and now occur naturally, especially along the western coastal region of Ecuador [1]. Many of these products are either not well-known or completely unknown, constituting a large number of underexploited native and exotic products that are of potential interest to the agroindustry and as natural sources of bioactive compounds with potential health benefits. Dietary patterns based on the frequent consumption of fruits and vegetables are closely related to a decrease in non-communicable chronic diseases, such as diabetes, cancer [2,3], and Alzheimer's [4,5], due to their high contents of phytochemicals, vitamins, minerals, and fiber, and to the interactive synergies between these components. Vitamin C (Vit C), a potent antioxidant that is widely found in fruits, is known to be a powerful antioxidant, with implications in several biological functions, such as collagen biosynthesis, L-carnitine, certain neurotransmitters, as well as in the metabolism of certain proteins, and has been shown to regenerate other antioxidants within the body, including $\alpha$-tocopherol (vitamin E) [6]. Therefore, regular intake is essential to maintain a healthy body and prevent diseases caused by oxidative stress and aging.

Based on the need to identify new sources of bioactive compounds, the scientific community is actively searching for new sources of bioactive compounds. The consumption of native or exotic fruits from tropical zones has increased due to the recognition of their nutritional and therapeutic values [7-9]. Studies on native products, mainly from South America, have also increased, as well as on the development of new food products based on these products; however, in the case of Ecuador, information about their chemical compositions and nutritional values is limited or often nonexistent.

Ecuador is divided into three continental regions: the coast (lowland regions between the Pacific Ocean and the Andes), the mountains (the Andean region), and the Amazon (east of the Andes mountain range), which are characterized by well-defined climatic conditions, vegetation, and nutritional patterns. The coastal region is divided into four provinces-Esmeraldas, Manabí, Guayas, and El Oro-which are characterized by lush vegetation, which contributes significantly to the fruticulture and horticulture of the country. This region is the main tropical fruits production area: native, exotic, or introduced in the country. The fruits are distributed nationwide and, in many cases, exported. Although some reports exist on the composition [10-12] and biological effects $[7,13]$ of some fruits traditionally consumed in Ecuador, these results are limited and do not allow us to identify the potential of these products as natural sources of bioactive compounds. These studies have been limited mainly to the profile of a group of bioactive compounds, such as vitamin $C$ and polyphenols, which, although they provide relevant information about the potential of some of these fruits, are not the only important values, since there are other compounds relevant to health and food quality that have not been studied in detail. With this backdrop, the aim of this study was to determine the principal bioactive compounds and antioxidant capacity of the main tropical fruits consumed in the coastal lowlands of Ecuador to elucidate their potential as possible sources of bioactive compounds with potential health benefits.

\section{Material and Methods}

\subsection{Fruit Samples}

We collected 19 fruits in 2018 during their corresponding crop season. They were purchased from popular markets in the coastal lowlands of Ecuador (provinces of Esmeraldas, Manabí, Guayas, and El Oro) (Table 1). Samples without blemishes or damage were selected based on a similar degree of ripeness on two different occasions. Three batches of samples $(1 \mathrm{~kg})$ were randomly collected on 
each occasion in each popular market and the specimens were identified by specialists at the Jardín Botánico of Quito, Ecuador, using the reference vouchers for specimens found at the center's herbarium. The edible parts of the samples were chopped and freeze-dried, ground to a fine powder and stored at $-20{ }^{\circ} \mathrm{C}$ until analysis.

Table 1. Major fruits consumed in the western coastal region of Ecuador.

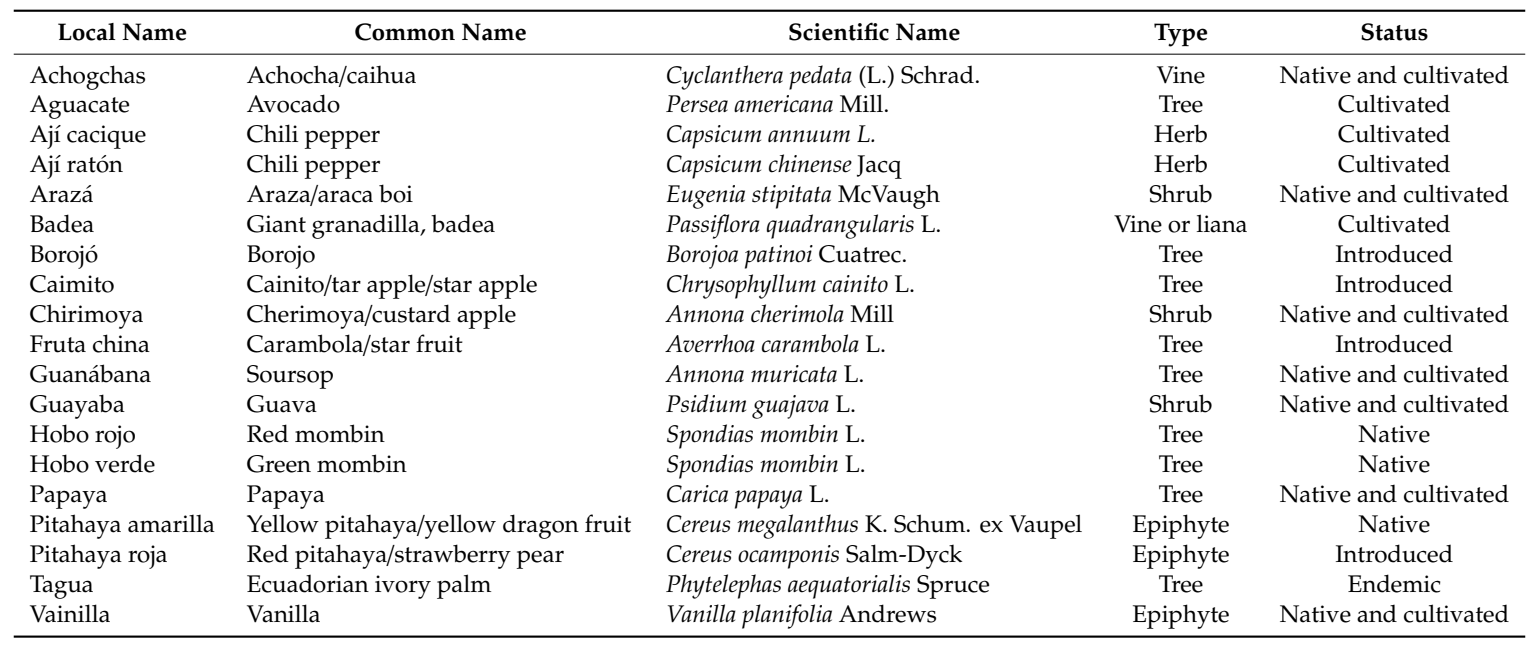

\subsection{Determination of Total Phenolic, Total Flavonoid, and Total Anthocyanin Contents}

The samples were lyophilized and subjected to hydroalcoholic extraction [14]. The total phenolic content (TPC) was determined using the Folin-Ciocalteu method [15] and the results expressed as milligrams of gallic acid equivalents (GAE) per 100 gram of fresh weight (FW) of fruit (mg GAE/100 g FW). The total flavonoid content (TFC) was determined spectrophotometrically [16] and the results expressed as milligrams of catechin equivalents (Cateq) per gram of FW of fruit (mg Cateq/g FW), and total anthocyanin (ACY) content was determined using a modified pH differential method [17], with minor modifications, and the results expressed as milligrams of pelargonidin 3-glucoside equivalents (PgEq) per gram of FW of fruits (mg PgEq/g FW).

\subsection{Equipment and Conditions for the HPLC-DAD Analysis}

The HPLC system (Agilent Technologies Series 1260, Santa Clara, CA, USA), equipped with a quaternary pump (Agilent Technologies 1260 Infinity G1312B, Santa Clara, CA, USA) and a diode array detector (Agilent Technologies 1260 Infinity G1315C DAD, Santa Clara, CA, USA), was used and adjusted according to the specific conditions of each method, as follows.

\subsubsection{Vitamin C Content Analysis}

Vitamin C was extracted following the procedure previously reported by Alvarez-Suarez et al. [7] and analyzed at $245 \mathrm{~nm}$ using the above-described HPLC system. An Eclipse Plus C18 column (5 $\mu \mathrm{m}$, $4.6 \times 150 \mathrm{~mm})$ was used as the stationary phase and $\mathrm{KH}_{2} \mathrm{PO}_{4}(50 \mathrm{mM}, \mathrm{pH} 2.5)$ was used as a solvent for elution in an isocratic gradient at a flow rate of $1 \mathrm{~mL} / \mathrm{min}$ for $20 \mathrm{~min}$. Ascorbic acid standard $\left(5 \mathrm{mg} / \mathrm{L}, \mathrm{y}=235.54 \mathrm{x}+53.13\right.$, coefficient of determination $\left(R^{2}\right)=0.9975$, limit of quantification (LOQ): $0.598 \mathrm{mg} / \mathrm{L}$ and limit of detection (LOD): $0.179 \mathrm{mg} / \mathrm{L}$ ) was used for the calibration curve and total vitamin C content is expressed as mg of ascorbic acid per $100 \mathrm{~g}$ of FW of fruits (mg Vit C/100 $\mathrm{g}$ FW).

\subsubsection{Carotenoid Content Analysis}

The carotenoids were extracted and saponified [7] and analyzed at $450 \mathrm{~nm}$ using the above-described HPLC system. An Eclipse Plus C18 column ( $5 \mu \mathrm{m}, 4.6 \times 250 \mathrm{~mm})$ was used as the stationary phase and methanol-isopropanol $(35: 65, v / v)$ was used in an isocratic gradient at a flow rate of $1 \mathrm{~mL} / \mathrm{min}$ for 
$15 \mathrm{~min}$ for elution. $\beta$-carotene, lutein, and lycopene contents were quantified using a calibration curve of the corresponding external standard and the results are expressed as mg per $100 \mathrm{~g}$ of FW of fruit.

\subsubsection{Organic Acids Content Analysis}

Organic acids were extracted according to the method previously reported [18]. A Zorbax SB-Aq column $(3.5 \mu \mathrm{m}, 4.6 \times 50 \mathrm{~mm})$ was used as the stationary phase and elution was performed with $20 \mathrm{mM}$ of $\mathrm{NaH}_{2} \mathrm{PO}_{4}(\mathrm{pH} 2.6) /$ acetonitrile $(99.5: 0.5, v / v)$ in an isocratic gradient at a flow rate of $0.8 \mathrm{~mL} / \mathrm{min} \mathrm{for}$ $35 \mathrm{~min}$. The detector was set to $210 \mathrm{~nm}$. Lactic, acetic, citric, and oxalic acids were used as standards and the results are expressed as $\mathrm{mg}$ or $\mathrm{g} / 100 \mathrm{~g}$ of fresh weight (FW) of fruit.

\subsection{HPLC-Refractive Index Detector Analysis of Glucose, Fructose, and Sucrose Contents}

Glucose and fructose contents were determined according to a previously reported method [19]. The ultra-high performance liquid chromatography (UHPLC) system (Dionex Ultimate 3000, Germering, Germany, Software Chromeleon) coupled with the refractive index (RI) detector was equipped with a quaternary pump (Dionex Ultimate 3000 UHPLC Focussed), degasser, and ERC RI 520 refractive index detector (RefractoMax, 521, Tokyo, Japan), and the chromatographic data were acquired using Chromeleon software. The stationary phase consisted of a Zorbax NH2 $(250 \times 4.6 \mathrm{~mm}, 5 \mu \mathrm{m})$ and elution was performed with $0.01 \mathrm{~N} \mathrm{H}_{2} \mathrm{SO}_{4}$ in an isocratic gradient at a flow rate of $1.0 \mathrm{~mL} / \mathrm{min}$ for $55 \mathrm{~min}$. External standards of glucose, fructose, and sucrose were used for identification and quantification using the respective calibration curves and the results are expressed as $\mathrm{g} / 100 \mathrm{~g}$ FW.

\subsection{Determination of Total Antioxidant Capacity (TAC)}

The hydroalcoholic extracts were used for TAC analyses using the ferric reducing antioxidant power (FRAP) assay [20] and the 2,2-diphenyl-1-picrylhydrazyl (DPPH) free radical method [21]. For the FRAP assay, $100 \mu \mathrm{L}$ of sample or Trolox standard solution was added to $900 \mu \mathrm{L}$ FRAP reagent (10:1:1 of sodium acetate (300 mM, pH 3.6), TPTZ (10 mM in HCl $40 \mathrm{mM})$, and ferric chloride (20 mM)). The reaction mixture was vortexed and allowed to stand for $5 \mathrm{~min}$ at room temperature in the dark and then the absorbance was read at $593 \mathrm{~nm}$ against a blank.

For the DPPH assay, $100 \mu \mathrm{L}$ of sample or Trolox standard solution was vigorously mixed with $400 \mu \mathrm{L}$ of DPPH solution in methanol $(0.2 \mathrm{mM})$. The mixtures were incubated for $15 \mathrm{~min}$ at room temperature and the absorbance of the solution $\left(\mathrm{Ab}_{\mathrm{sol}}\right)$ was measured at $517 \mathrm{~nm}$. The sample blank (B1) consisted of $600 \mu \mathrm{L}$ of $70 \%$ methanol and $400 \mu \mathrm{L}$ of DPPH, whereas the fruits blank (B2) contained $100 \mu \mathrm{L}$ of sample, $500 \mu \mathrm{Ll}$ of $70 \%$ methanol, and $400 \mu \mathrm{L}$ of methanol. The DPPH scavenging activity was calculated using the following equation:

$$
\text { DPPH scavenging activity }(\%)=\left[1-\left\{\left(\mathrm{Ab}_{\mathrm{sol}}-\mathrm{B} 2\right) / \mathrm{B} 1\right\}\right] \times 100
$$

The results are expressed as $\mu \mathrm{mol}$ of Trolox equivalents (TEq) per gram of fresh weight of fruit FW ( $\mu$ mol TEq per $g$ FW) for both assays.

\subsection{Statistical Analysis}

Statistical analyses were performed using IBM SPSS Statistics for Windows version 20.0. A multivariate analysis (MANOVA) was applied to determine the chemical composition and TAC with regards to the fruit species. Variables describing chemical composition and antioxidant properties were treated as dependent variables in the MANOVA and some were previously log transformed for homogeneity fulfillment. The MANOVA analysis was essentially used to test whether or not the fruit type simultaneously explained a statistically significant amount of variance in the chemical composition and antioxidant properties. The Bonferroni correction was used for post-hoc analysis, accounting for comparison between multiples groups. $p<0.05$ was considered statistically significant. The samples were analyzed in triplicate, and results are reported as mean \pm standard deviation (SD). 


\section{Results and Discussion}

\subsection{Total Phenolic, Flavonoid, Anthocyanin, and Vitamin C Contents}

The analyzed samples showed significant differences $(p<0.05)$ in the contents of the different bioactive compounds (Table 2). The total phenolic content (TPC) in the different fruits ranged between $149.89 \mathrm{mg}$ (borojo) and $4436.01 \mathrm{mg}$ (carambola) GAE/100 g FW. TPC was also used to classify the fruits into three groups according to the classification previously proposed by Vasco et al. [10]: low ( $<100 \mathrm{mg}$ of GAE/100 $\mathrm{g} \mathrm{FW),} \mathrm{medium} \mathrm{(100-500} \mathrm{mg} \mathrm{of} \mathrm{GAE/100} \mathrm{g}$ FW), and high contents (>500 mg of GAE/100 g FW). According to this classification, $63.2 \%$ of the fruits were classified as having a high TPC and $36.8 \%$ were in the medium content category, which is in agreement with the values previously reported in fruits from tropical regions [22-25]. The total flavonoid content (TFC) ranged between 1.53 (giant granadilla) and $53.28 \mathrm{mg}$ (carambola) CatEq/g FW, where carambola showed the best results for both TPC and TFC assays. In terms of anthocyanin content (ACY), the lowest values were found in borojo fruit (0.24 mg PgEq/g FW), and the highest in chili pepper (ají cacique) (1.35 mg PgEq/g FW).

The values of vitamin $C$ in the fruits analyzed ranged between $2.08 \mathrm{mg}$ of Vit C/100 $\mathrm{g}$ of FW (avocado) and $509.63 \mathrm{mg}$ of Vit C/100 g of FW (guava), in line with the results previously reported in different fruits $[23,24,26,27]$ (Table 2). According to the classification proposed by Ramful et al. [28] for the Vit C content in fruits, $64.7 \%$ of the fruits analyzed here were classified as high $(>50 \mathrm{mg} / 100 \mathrm{~g}$ of $\mathrm{FW}$ ), and $35.3 \%$ as low ( $<30 \mathrm{mg} / 100 \mathrm{~g}$ of $\mathrm{FW})$. In vanilla and Ecuadorian ivory palm, vitamin C was not detectable in our determination. Following the directives of the Food and Nutrition Board at the Institute of Medicine of the National Academies [29], the recommended dietary allowances (RDAs) for vitamin C for adults over 19 years old are $90 \mathrm{mg}$ for men and $75 \mathrm{mg}$ for women. Therefore, following these recommendations, $58 \%$ of the fruits analyzed here exceeded the recommended limits per $100 \mathrm{~g}$ of FW, which demonstrates the high content of this vitamin in the fruits consumed in this region.

\subsection{Total Carotenoid Content}

Total carotenoid contents in the fruits analyzed here are shown in Figure 1. The highest concentrations of $\beta$-carotene $(1.88 \mathrm{mg} / 100 \mathrm{~g}$ of FW) and lutein $(22.44 \mathrm{mg} / 100 \mathrm{~g}$ of FW) were found in chili pepper (aji ratón), and cainito fruits were the main source of lycopene $(1.87 \mathrm{mg} / 100 \mathrm{~g}$ of FW). Previously, our group reported the carotenoid contents of wild Andean blackberry (Rubus glaucus Benth) [13], Andean blueberry (Vaccinium floribundum Kunth) [13], and capuli cherry (Prunus serotina Ehr. subsp. capuli (Cav.) McVaugh) [7] from the highlands of Ecuador; however, beyond these results, no data were found in the literature regarding the carotenoid content of other fruits from Ecuador. Therefore, we assume this is the first report regarding the carotenoid composition of these fruits. Most of the results reported here are within the range of those values previously reported in fruits from other geographical regions [30-34]. However, in some cases, such as in chili pepper and caimito, the values are higher than those usually reported in other fruits but in line with those previously reported in fruits from the Northern Argentinean Andean region [35]. According to Khayyat et al. [36], the exposure of plants to differences in altitude and the incidence of ultraviolet light, as well as their exposure to low temperatures, has an important effect on their chemical composition. Ecuador is located on the equator, where the sun's rays strike the earth's surface more directly (nearly perpendicular or close to a $90^{\circ}$ angle) most hours of the day. Therefore, the conditions to which the plants of this region are exposed could justify the high concentrations of carotenoids and other phytocompounds in comparison with those of other regions. Following the intake recommendations for carotenoids [29], all the fruits analyzed here meet the recommendations for daily consumption for this type of compound. 
Table 2. Chemical composition and antioxidant capacity of the major fruits consumed in the western coastal region of Ecuador.

\begin{tabular}{|c|c|c|c|c|c|c|}
\hline \multirow[b]{2}{*}{ Common Name } & \multicolumn{2}{|c|}{ TAC ( $\mu \mathrm{mol}$ TEq/g FW) } & \multicolumn{4}{|c|}{ Bioactive Compounds } \\
\hline & FRAP & DPPH & $\begin{array}{c}\text { TPC } \\
\text { (mg GAE/100 g FW) }\end{array}$ & $\begin{array}{c}\text { TFC } \\
\text { (mg CatEq/g FW) }\end{array}$ & $\begin{array}{c}\text { ACY } \\
\text { (mg PgEq/g FW) }\end{array}$ & $\begin{array}{c}\text { Vit C } \\
\text { (mg Vit } C / 100 \text { g FW) }\end{array}$ \\
\hline Achocha & $264.78 \pm 21.14^{\mathrm{e}}$ & $0.24 \pm 0.05^{\mathrm{i}}$ & $482.07 \pm 48.99 \mathrm{~d}$ & $2.88 \pm 0.23^{\mathrm{e}}$ & $0.68 \pm 0.07^{b}$ & $18.03 \pm 4.07^{\mathrm{f}}$ \\
\hline Avocado & $189.09 \pm 37.31^{\mathrm{e}}$ & $u d$ & $317.02 \pm 10.42^{d}$ & $2.50 \pm 0.63^{\mathrm{e}}$ & $0.42 \pm 0.09^{c}$ & $1.63 \pm 0.43 g$ \\
\hline Chili pepper & $1666.66 \pm 139.00^{b}$ & $91.47 \pm 5.56^{\mathrm{e}}$ & $1282.15 \pm 352.90^{b}$ & $7.40 \pm 1.17^{\mathrm{c}}$ & $1.33 \pm 0.26^{\mathrm{a}}$ & $248.13 \pm 56.53^{c}$ \\
\hline Chili pepper & $923.05 \pm 53.85^{\mathrm{c}}$ & $85.49 \pm 5.97^{\mathrm{e}}$ & $1184.67 \pm 199.85^{b}$ & $3.61 \pm 0.38^{d}$ & $0.76 \pm 0.07^{b}$ & $294.00 \pm 27.36^{c}$ \\
\hline Araza & $24.56 \pm 5.35^{\mathrm{h}}$ & $210.78 \pm 16.50^{\mathrm{d}}$ & $543.32 \pm 21.94 \mathrm{~d}$ & $1.84 \pm 0.46^{\mathrm{e}}$ & $0.32 \pm 0.04^{c}$ & $181.13 \pm 13.01^{\mathrm{d}}$ \\
\hline Giant Granadilla & $387.89 \pm 33.11^{d}$ & $90.68 \pm 8.05^{\mathrm{e}}$ & $324.18 \pm 36.35^{d}$ & $1.79 \pm 0.24^{\mathrm{e}}$ & $0.33 \pm 0.02^{c}$ & $277.72 \pm 22.24^{c}$ \\
\hline Borojo & $3.66 \pm 0.92^{j}$ & $50.07 \pm 8.18^{g}$ & $142.53 \pm 16.20^{\mathrm{e}}$ & $3.88 \pm 0.29 \mathrm{~d}$ & $0.30 \pm 0.05^{c}$ & $u d$ \\
\hline Cainito & $1591.93 \pm 398.06^{b}$ & $537.61 \pm 43.81^{\mathrm{c}}$ & $1181.44 \pm 172.13^{b}$ & $8.25 \pm 0.37^{c}$ & $0.83 \pm 0.10^{b}$ & $12.23 \pm 1.61^{\mathrm{f}}$ \\
\hline Cherimoya & $1167.18 \pm 183.84^{c}$ & $843.80 \pm 19.28^{b}$ & $1472.18 \pm 332.49^{b}$ & $23.43 \pm 5.00^{b}$ & $0.27 \pm 0.05^{c}$ & $78.96 \pm 6.13^{e}$ \\
\hline Carambola & $3370.94 \pm 308.02^{a}$ & $1215.34 \pm 101.98^{a}$ & $4280.83 \pm 673.83^{a}$ & $48.52 \pm 5.40^{\mathrm{a}}$ & $0.51 \pm 0.07^{b}$ & $199.44 \pm 11.28^{\mathrm{d}}$ \\
\hline Soursop & $422.11 \pm 57.72^{\mathrm{d}}$ & $92.96 \pm 9.46^{\mathrm{e}}$ & $485.85 \pm 36.38^{\mathrm{d}}$ & $2.15 \pm 0.18^{\mathrm{e}}$ & $0.21 \pm 0.06^{c}$ & $106.00 \pm 8.50^{\mathrm{d}}$ \\
\hline Guava & $1568.48 \pm 273.20^{b}$ & $607.48 \pm 18.96^{c}$ & $1163.94 \pm 159.50^{b}$ & $5.80 \pm 0.53^{c}$ & $0.57 \pm 0.05^{b}$ & $496.73 \pm 14.32^{\mathrm{a}}$ \\
\hline Red mombin & $45.31 \pm 6.85^{\mathrm{g}}$ & $1081.79 \pm 50.18^{a}$ & $827.51 \pm 14.58^{c}$ & $4.39 \pm 0.34^{\mathrm{d}}$ & $0.35 \pm 0.03^{c}$ & $201.02 \pm 17.93^{\mathrm{d}}$ \\
\hline Green mombin & $46.63 \pm 8.39 \mathrm{~g}$ & $519.18 \pm 30.99^{c}$ & $787.87 \pm 38.87^{c}$ & $4.40 \pm 0.49^{\mathrm{d}}$ & $0.33 \pm 0.03^{c}$ & $176.25 \pm 14.03^{\mathrm{d}}$ \\
\hline Papaya & $571.26 \pm 59.62^{d}$ & $77.77 \pm 8.35^{\mathrm{f}}$ & $341.70 \pm 42.97^{\mathrm{d}}$ & $1.99 \pm 0.48^{\mathrm{e}}$ & $0.54 \pm 0.04^{b}$ & $341.98 \pm 20.22^{b}$ \\
\hline Red pitahaya & $10.53 \pm 2.30^{\mathrm{i}}$ & $84.61 \pm 3.89 \mathrm{e}$ & $251.22 \pm 39.04 \mathrm{e}^{\mathrm{e}}$ & $3.41 \pm 0.34^{d}$ & $0.32 \pm 0.02^{c}$ & $12.93 \pm 2.52^{f}$ \\
\hline Ecuadorian ivory palm & $381.85 \pm 46.36^{\mathrm{d}}$ & $116.06 \pm 7.55^{\mathrm{d}}$ & $203.54 \pm 20.008^{e}$ & $4.50 \pm 0.34^{\mathrm{d}}$ & $0.34 \pm 0.06^{c}$ & $u d$ \\
\hline Vanilla & $78.86 \pm 9.64^{\mathrm{f}}$ & $530.32 \pm 22.88^{c}$ & $1447.25 \pm 171.05^{b}$ & $6.71 \pm 0.66^{c}$ & $0.52 \pm 0.09^{b}$ & $u d$ \\
\hline
\end{tabular}

Note: Values are expressed as means \pm SD. Mean values within a column sharing the same letter are not significantly different after Bonferroni post-hoc analysis $(p<0.05)$. Each sample was analyzed in triplicate. ${ }^{u d}$ — undetectable; FRAP—ferric reducing antioxidant power; DPPH-2,2-diphenyl-1-picrylhydrazyl free radical method; TPC—-total phenolic content; TFC—-total flavonoid content; ACY-total anthocyanin content; Vit C-vitamin C content. 
A

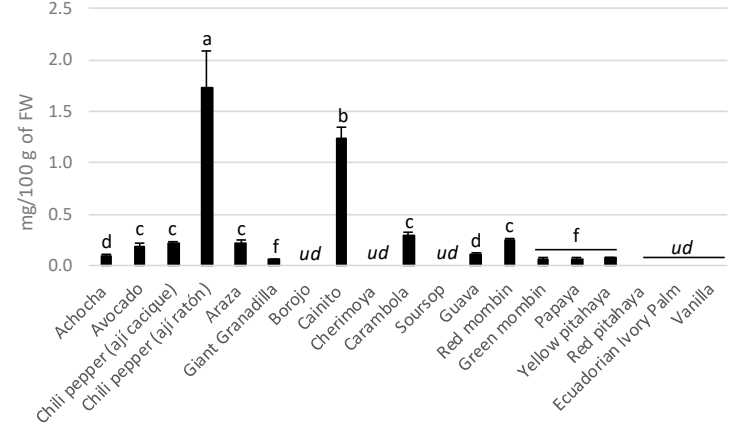

B

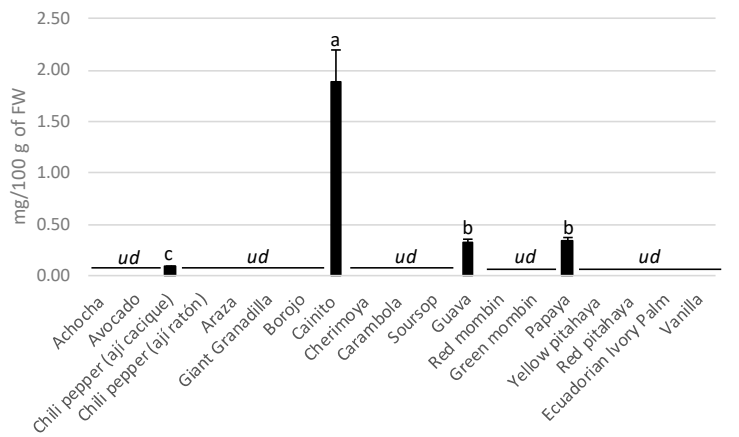

C

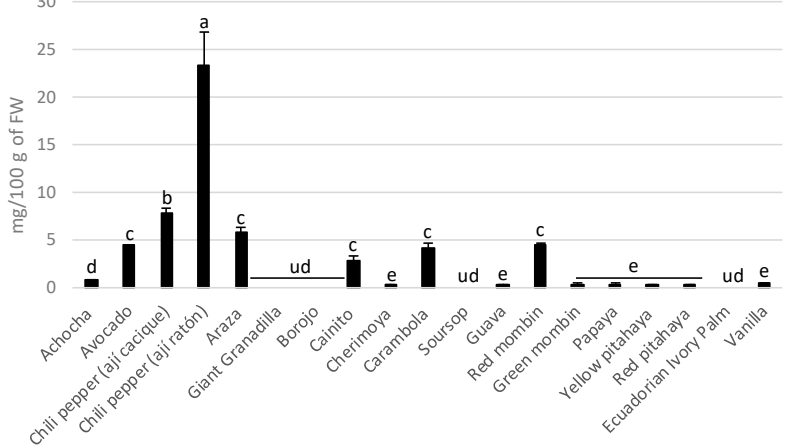

Figure 1. The carotenoid contents in the major fruits consumed in the western coastal region of Ecuador: (A) $\beta$-carotene, (B) lycopene, and (C) lutein contents. Values are expressed as means \pm SD. Bars with different letters are significantly different per Bonferroni post-hoc analysis $(p<0.05)$. Samples were analyzed in triplicate. ${ }^{u d}$ - undetectable.

\subsection{Organic Acids Contents}

Organic acids play an important role in fruit in terms of their texture and flavor, which is fundamental to consumer acceptance [37]. In this context, the total contents of lactic, acetic, citric, and oxalic acids were determined in the fruits (Table 3). The highest lactic acid value was found in soursop fruits (13.56 g/100 g of FW); Ecuadorian ivory palm $(8.01 \mathrm{~g} / 100 \mathrm{~g}$ of FW) and guava fruits $(7.39 \mathrm{~g} / 100 \mathrm{~g}$ of FW) showed the highest acetic acid content.

Guava also had the highest content of citric acid (2.12 g/100 g of FW), whereas the highest concentration of oxalic acid was found in carambola $(2.15 \mathrm{~g} / 100 \mathrm{~g}$ of FW). We must emphasize that it was difficult to find reports on the content of organic acids in the fruits produced both in this region and in Ecuador; therefore, in our opinion, the results reported here constitute the first study regarding the profile of organic acids in fruits from Ecuador. We compared our results with those previously reported in fruits from other geographical areas and it was found that the values reported here are within the ranges previously described $[18,37]$. Although the values reported here could be compared with those from previous reports, it should be taken into account that the organic acid content depends on the fruit's stage of development and on different environmental and storage factors [36,38], allowing one to justify the differences between our results and those previously reported in fruits from other geographical regions. 
Table 3. Contents of organic acids in the principal fruits consumed in the western coastal region of Ecuador.

\begin{tabular}{ccccc}
\hline \multirow{2}{*}{ Common Name } & \multicolumn{3}{c}{ Organic Acids (mg/100 g of FW) } \\
\cline { 2 - 5 } & Lactic Acid & Acetic Acid & Citric Acid & Oxalic Acid \\
\hline Achocha & $1.85 \pm 0.01^{\mathrm{c}}$ & $1.66 \pm 0.02^{\mathrm{b}}$ & $0.47 \pm 0.05^{\mathrm{c}}$ & $0.04 \pm 0.00^{\mathrm{e}}$ \\
Avocado & $2.01 \pm 0.30^{\mathrm{c}}$ & $2.83 \pm 0.16^{\mathrm{b}}$ & $0.03 \pm 0.00^{\mathrm{e}}$ & $0.05 \pm 0.00^{\mathrm{e}}$ \\
Chili pepper & $1.65 \pm 0.13^{\mathrm{c}}$ & $0.76 \pm 0.02^{\mathrm{c}}$ & $1.88 \pm 0.04^{\mathrm{a}}$ & $0.05 \pm 0.00^{\mathrm{e}}$ \\
Chili pepper & $4.44 \pm 0.71^{\mathrm{b}}$ & $0.59 \pm 0.03^{\mathrm{c}}$ & $0.42 \pm 0.05^{\mathrm{c}}$ & $0.02 \pm 0.00^{\mathrm{e}}$ \\
Araza & $5.18 \pm 0.07^{\mathrm{b}}$ & $0.53 \pm 0.01^{\mathrm{c}}$ & $0.11 \pm 0.00^{\mathrm{d}}$ & $u{ }^{\mathrm{d}}$ \\
Giant Granadilla & $0.56 \pm 0.03^{\mathrm{e}}$ & $1.29 \pm 0.09^{\mathrm{b}}$ & $0.90 \pm 0.01^{\mathrm{b}}$ & $0.13 \pm 0.00^{\mathrm{d}}$ \\
Borojo & $1.48 \pm 0.17^{\mathrm{c}}$ & $0.12 \pm 0.01^{\mathrm{d}}$ & $0.02 \pm 0.00^{\mathrm{e}}$ & $0.58 \pm 0.05^{\mathrm{b}}$ \\
Cainito & $1.32 \pm 0.01^{\mathrm{c}}$ & $1.65 \pm 0.07^{\mathrm{b}}$ & $0.04 \pm 0.00^{\mathrm{e}}$ & $0.21 \pm 0.01^{\mathrm{c}}$ \\
Cherimoya & $1.12 \pm 0.03^{\mathrm{d}}$ & $1.57 \pm 0.01^{\mathrm{b}}$ & $0.53 \pm 0.00^{\mathrm{c}}$ & $0.01 \pm 0.00^{\mathrm{e}}$ \\
Carambola & $0.93 \pm 0.04^{\mathrm{d}}$ & $0.67 \pm 0.06^{\mathrm{c}}$ & $0.02 \pm 0.00^{\mathrm{e}}$ & $2.15 \pm 0.11^{\mathrm{a}}$ \\
Soursop & $13.56 \pm 2.00^{\mathrm{a}}$ & $1.42 \pm 0.24^{\mathrm{b}}$ & $0.41 \pm 0.02^{\mathrm{c}}$ & $0.02 \pm 0.00^{\mathrm{e}}$ \\
Guava & $0.92 \pm 0.06^{\mathrm{d}}$ & $7.39 \pm 0.64^{\mathrm{a}}$ & $2.12 \pm 0.26^{\mathrm{a}}$ & $0.06 \pm 0.00^{\mathrm{e}}$ \\
Red mombin & $0.64 \pm 0.03^{\mathrm{e}}$ & $1.54 \pm 0.04^{\mathrm{b}}$ & $0.12 \pm 0.01^{\mathrm{d}}$ & $0.02 \pm 0.00^{\mathrm{e}}$ \\
Green mombin & $0.41 \pm 0.05^{\mathrm{e}}$ & $1.39 \pm 0.03^{\mathrm{b}}$ & $0.09 \pm 0.01^{\mathrm{d}}$ & $u d$ \\
Papaya & $1.82 \pm 0.36^{\mathrm{c}}$ & $0.08 \pm 0.00^{\mathrm{d}}$ & $1.10 \pm 0.02^{\mathrm{b}}$ & $0.23 \pm 0.01^{\mathrm{c}}$ \\
Yellow pitahaya & $0.58 \pm 0.04^{\mathrm{e}}$ & $0.13 \pm 0.03^{\mathrm{d}}$ & $0.88 \pm 0.01^{\mathrm{b}}$ & $0.07 \pm 0.00^{\mathrm{e}}$ \\
Red pitahaya & $2.12 \pm 0.02^{\mathrm{c}}$ & $u^{\mathrm{y}}$ & $0.08 \pm 0.00^{\mathrm{d}}$ & $0.14 \pm 0.01^{\mathrm{d}}$ \\
Ecuadorian ivory palm & $4.66 \pm 0.18^{\mathrm{b}}$ & $8.01 \pm 0.38^{\mathrm{a}}$ & $0.11 \pm 0.01^{\mathrm{d}}$ & $0.02 \pm 0.00^{\mathrm{e}}$ \\
Vanilla & $0.07 \pm 0.01^{\mathrm{f}}$ & $0.02 \pm 0.00^{\mathrm{e}}$ & $1.98 \pm 0.73^{\mathrm{a}}$ & $0.02 \pm 0.00^{\mathrm{e}}$ \\
\hline
\end{tabular}

Values are expressed as means \pm SD. Mean values within a column with a different letter are significantly different after Bonferroni post-hoc analysis $(p<0.05)$. Samples were analyzed in triplicate. ${ }^{u d}$-undetectable.

\subsection{Sugar Content}

Fruits and vegetables naturally contain sucrose, glucose, and fructose, among other carbohydrates in varying amounts, and their contents directly affect the quality and flavor of fruits [19]. Sugars found in fruits and vegetables are considered healthier than added sugars, and therein lies the importance of knowing the main natural sources for each, to incorporate them into one's diet. The glucose, fructose, and sucrose contents in the fruits analyzed are presented in Table 4. Giant granadilla showed the highest values of glucose ( $5.28 \mathrm{~g} / 100 \mathrm{~g}$ of FW); red mombin was the principal source of fructose $(7.22 \mathrm{~g} / 100 \mathrm{~g}$ of FW), and guava of sucrose $(7.40 \mathrm{~g} / 100 \mathrm{~g}$ of FW). However, considering the sum of these three sugars, red mombin showed the highest values, followed by guava, whereas the lowest values were found in the fruits of green mombin, carambola, and Ecuadorian ivory palm (Table 4). These results are within the range of those previously reported in fruits from other geographical regions; however, these values could also be considered low in comparison with those previously reported [27], which could be considered positive if considering the negative effect of excess sugar consumption on health. The RDA [39] established for carbohydrate is $130 \mathrm{~g}$ per day for adults and children. Following these recommendations, all the fruits analyzed could be considered low in carbohydrate contributions for $100 \mathrm{~g}$ of FW. In this sense, $100 \mathrm{~g}$ of the fruits of red mombin, which were those that showed the highest total sugar content (11.04 g/100 of FW) (glucose + fructose + sucrose), as the main sugars contributed by fruits, would provide approximately only $8.5 \%$ of the total recommended carbohydrates for a day (130 g of total carbohydrates). 
Table 4. Sugar contents in the principal fruits consumed in the western coastal region of Ecuador.

\begin{tabular}{ccccc}
\hline \multirow{2}{*}{ Common Name } & \multicolumn{3}{c}{ Sugar Content (g/100 g of FW) } \\
\cline { 2 - 5 } & Glucose & Fructose & Sucrose & Total $\sum$ Gluc+Fruct+Sucr \\
\hline Achocha & $2.04 \pm 0.32^{\mathrm{c}}$ & $2.12 \pm 0.20^{\mathrm{c}}$ & $1.80 \pm 0.62^{\mathrm{c}}$ & $5.97 \pm 0.26^{\mathrm{c}}$ \\
Avocado & $0.56 \pm 0.04^{\mathrm{d}}$ & $4.86 \pm 0.23^{\mathrm{b}}$ & $0.28 \pm 0.09^{\mathrm{e}}$ & $5.70 \pm 1.56^{\mathrm{c}}$ \\
Chili pepper & $u d^{\mathrm{y}}$ & $0.06 \pm 0.01^{\mathrm{g}}$ & $0.41 \pm 0.02^{\mathrm{e}}$ & $0.47^{\mathrm{a}} \pm .12^{\mathrm{f}}$ \\
Chili pepper & $0.02 \pm 0.00^{\mathrm{f}}$ & $4.47 \pm 0.71^{\mathrm{b}}$ & $0.60 \pm 0.01^{\mathrm{d}}$ & $5.10 \pm 1.42^{\mathrm{c}}$ \\
Araza & $0.54 \pm 0.02^{\mathrm{d}}$ & $0.18 \pm 0.04^{\mathrm{f}}$ & $0.07 \pm 0.00^{\mathrm{f}}$ & $0.80 \pm 0.14^{\mathrm{f}}$ \\
Giant Granadilla & $5.88 \pm 0.67^{\mathrm{a}}$ & $0.26 \pm 0.03^{\mathrm{f}}$ & $0.52 \pm 0.08^{\mathrm{d}}$ & $6.66 \pm 1.79^{\mathrm{c}}$ \\
Borojo & $2.82 \pm 0.10^{\mathrm{b}}$ & $1.84 \pm 0.16^{\mathrm{c}}$ & $0.27 \pm 0.03^{\mathrm{e}}$ & $4.93 \pm 1.27^{\mathrm{c}}$ \\
Cainito & $0.04 \pm 0.00^{\mathrm{f}}$ & $1.60 \pm 0.06^{\mathrm{c}}$ & $1.63 \pm 0.07^{\mathrm{c}}$ & $3.27 \pm 0.84^{\mathrm{d}}$ \\
Cherimoya & $3.40 \pm 0.38^{\mathrm{b}}$ & $0.51 \pm 0.11^{\mathrm{e}}$ & $0.05 \pm 0.00^{\mathrm{f}}$ & $3.96 \pm 1.27^{\mathrm{d}}$ \\
Carambola & $0.65 \pm 0.13^{\mathrm{d}}$ & $0.64 \pm 0.11^{\mathrm{e}}$ & $0.04 \pm 0.00^{\mathrm{f}}$ & $1.33 \pm 0.35^{\mathrm{e}}$ \\
Soursop & $0.42 \pm 0.01^{\mathrm{d}}$ & $0.67 \pm 0.05^{\mathrm{e}}$ & $1.92 \pm 0.06^{\mathrm{c}}$ & $3.01 \pm 0.80^{\mathrm{d}}$ \\
Guava & $0.15 \pm 0.02^{\mathrm{e}}$ & $0.92 \pm 0.01^{\mathrm{d}}$ & $7.40 \pm 0.65^{\mathrm{a}}$ & $8.47 \pm 2.18^{\mathrm{b}}$ \\
Red mombin & $1.65 \pm 0.17^{\mathrm{c}}$ & $7.22 \pm 0.08^{\mathrm{a}}$ & $2.17 \pm 0.22^{\mathrm{c}}$ & $11.04 \pm 2.94^{\mathrm{a}}$ \\
Green mombin & $1.51 \pm 0.27^{\mathrm{c}}$ & $0.17 \pm 0.02^{\mathrm{f}}$ & $0.08 \pm 0.00^{\mathrm{f}}$ & $1.76 \pm 0.80^{\mathrm{e}}$ \\
Papaya & $1.48 \pm 0.34^{\mathrm{c}}$ & $0.71 \pm 0.04^{\mathrm{d}}$ & $3.45 \pm 0.29^{\mathrm{b}}$ & $5.64 \pm 1.40^{\mathrm{c}}$ \\
Yellow pitahaya & $2.81 \pm 0.13^{\mathrm{b}}$ & $0.82 \pm 0.10^{\mathrm{d}}$ & $0.75 \pm 0.04^{\mathrm{d}}$ & $4.38 \pm 1.17^{\mathrm{c}}$ \\
Red pitahaya & $u d$ & $0.21 \pm 0.01^{\mathrm{f}}$ & $2.21 \pm 0.18^{\mathrm{c}}$ & $2.42 \pm 0.82^{\mathrm{d}}$ \\
Ecuadorian ivory palm & $0.46 \pm 0.06^{\mathrm{d}}$ & $0.86 \pm 0.03^{\mathrm{d}}$ & $0.02 \pm 0.00^{\mathrm{f}}$ & $1.34 \pm 0.42^{\mathrm{e}}$ \\
Vanilla & $0.17 \pm 0.02^{\mathrm{e}}$ & $0.51 \pm 0.06^{\mathrm{e}}$ & $1.48 \pm 0.68^{\mathrm{c}}$ & $2.16 \pm 0.67^{\mathrm{d}}$
\end{tabular}

Note: Values are expressed as means \pm standard deviation (SD). Mean values within a column with different letters are significantly different after Bonferroni post-hoc analysis $(p<0.05)$. Samples were analyzed in triplicate. $u d$ - undetectable.

\subsection{Total Antioxidant Activity}

In relation to the total antioxidant capacity (TAC), the highest values for both methods (FRAP, $\mathrm{DPPH}$ ) were found in carambola (Table 2). In addition, given that the fruits' health benefits are influenced by the interaction of their different bioactive compounds, a factorial analysis was conducted with the principal variables (TFC, TPC, FRAP, DPPH, ACY, $\beta$-carotene, lutein, and Vit C) related to the $\mathrm{TAC}$, using the varimax rotation to determine which fruit was the main contributor for of each of them. Three factors were extracted (principal component (PC) PC1, PC2, and PC3), which explained $77.46 \%$ of the variance. The rotated matrix clearly described the main contributions of each component. The first two components explained $64.78 \%$ of the total variance and encompassed the majority of the variables (Table 5), while Figure 2 shows the distribution of the PC1 and PC2 variables. Carambola was found to be the main contributor in terms of TPC and TFC, and TAC (Figure 2A), whereas chili pepper (ají ratón) proved to be the main source of lutein, $\beta$-carotene, as well as ACY, and Vit C (Figure 2B). The reason that carambola had the highest results for TAC could be explained by its TPC and TFC, which seem to be the principal contributors to the TAC in the fruits analyzed here (Table 2). Indeed, the correlation analysis clearly shows that FRAP and DPPH are highly correlated with TPC and TFC. Moreover, FRAP but not DPPH is related to vitamin C, ACY, and other compounds with antioxidant effects, which may in turn be related to the antioxidant mechanisms of the compounds present in these fruits, which may have more reducing activity (FRAP) than radical scavenging (DPPH) activity (Table 6). Therefore, although Vit $\mathrm{C}$ and carotenoids have been associated with important antioxidant activity in fruits [40], according to the high correlation found here between TFC, TPC, FRAP, and DPPH, it could be hypothesized that polyphenols could be mainly responsible for the TAC in the fruits studied here, in accordance with previous reports [22,34]. 
Table 5. Rotated coupon in factorial analysis.

\begin{tabular}{cccc}
\hline Variable & PC1 & PC2 & PC3 \\
\hline TFC & 0.951 & -0.014 & -0.037 \\
TPC & 0.939 & 0.218 & 0.025 \\
FRAP & 0.836 & 0.322 & 0.262 \\
DPPH & 0.835 & -0.090 & -0.002 \\
Lutein & -0.015 & 0.935 & -0.029 \\
B-Carotene & 0.003 & 0.774 & 0.441 \\
ACY & 0.091 & 0.604 & 0.469 \\
Vit C & 0.218 & 0.546 & -0.203 \\
Licp & 0.072 & 0.002 & 0.952 \\
\hline
\end{tabular}

Note: FRAP—ferric reducing antioxidant power; DPPH-2,2-diphenyl-1-picrylhydrazyl free radical method; TPC — total phenolic content; TFC — total flavonoid content; Vit C - vitamin C content; ACY - total anthocyanin content; $\beta$-Carot—-total $\beta$-carotene content; Licp—total lycopene content; Lut-total lutein content.
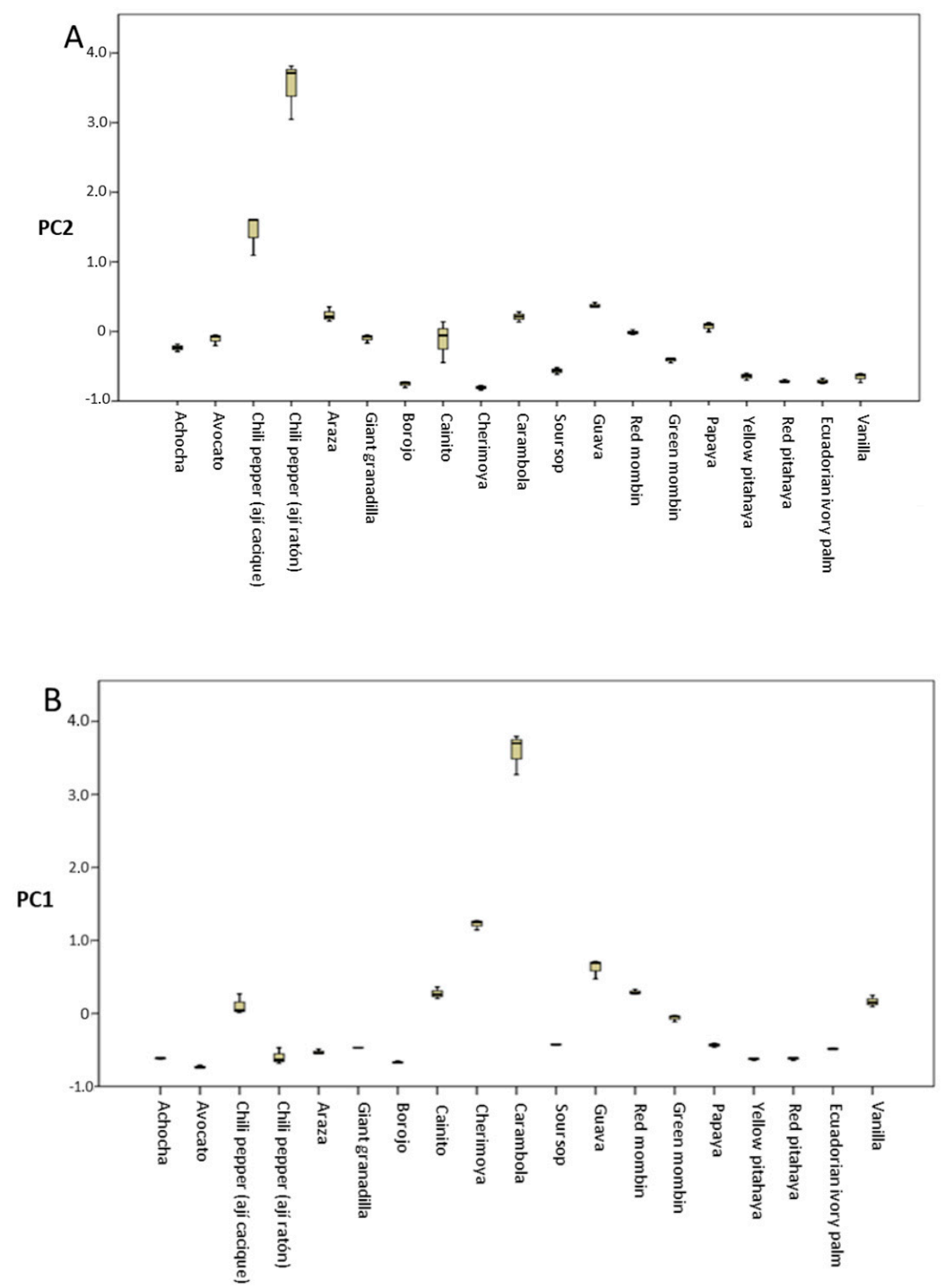

Figure 2. Factorial analysis and cluster using varimax rotation with the TFC, TPC, FRAP, DPPH, Lut, $\beta$-carot Lut, ACY, and Vit C values. The distributions of (A) PC1 and (B) PC2. FRAP-ferric reducing antioxidant power; DPPH-2,2-diphenyl-1-picrylhydrazyl free radical method; TPC —-total phenolic content; TFC - total flavonoid content; Vit C—vitamin C content; ACY-total anthocyanin content; $\beta$-Carot-total $\beta$-carotene content; Licp-total lycopene content; Lut-total lutein content. 
Table 6. Correlation matrix for chemical composition and total antioxidant capacity (TAC) in the fruits analyzed.

\begin{tabular}{|c|c|c|c|c|c|c|c|c|c|}
\hline Variables & FRAP & DPPH & TPC & TFC & Vit C & $\mathrm{ACY}$ & $\beta$-Carot & Licp & Lut \\
\hline FRAP & 1 & $0.526^{* *}$ & $0.838^{* *}$ & $0.797^{* *}$ & $0.366^{* *}$ & $0.449^{* *}$ & 0.293 * & 0.294 * & 0.217 \\
\hline DPPH & & 1 & $0.719 * *$ & $0.699^{* *}$ & 0.201 & -0.084 & 0.012 & 0.126 & -0.047 \\
\hline TPC & & & 1 & $0.908^{* *}$ & 0.210 & 0.250 & 0.197 & 0.058 & 0.214 \\
\hline TFC & & & & 1 & 0.045 & 0.049 & 0.016 & -0.015 & 0.025 \\
\hline Vit C & & & & & 1 & $0.261 *$ & 0.168 & 0.001 & 0.295 * \\
\hline $\mathrm{ACY}$ & & & & & & 1 & $0.437^{* *}$ & $0.345^{* *}$ & $0.445^{* *}$ \\
\hline$\beta$-Carot & & & & & & & 1 & $0.433^{* *}$ & $0.821 * *$ \\
\hline Licp & & & & & & & & 1 & -0.050 \\
\hline Lut & & & & & & & & & 1 \\
\hline
\end{tabular}

\section{Conclusions}

In this study, selected bioactive compounds and antioxidant capacity were determined for the main fruits consumed in Ecuador's western coastal region, with the aim of elucidating their potential as dietary sources of bioactive compounds with beneficial effects on human health. Carambola is the main contributor in terms of the total phenolic and flavonoid contents and total antioxidant capacity, whereas chili pepper (ají ratón) is the main contributor of lutein, $\beta$-carotene, vitamin $C$, and anthocyanins. The correlation analysis showed that the total phenolic and flavonoid contents are the main contributors to the total antioxidant capacity of the fruits. In general, the results presented here, to the best of our knowledge, constitute the first report of the contents of important bioactive compounds with relevant effects on human health, as well as other compounds that are related to the quality of these exotic fruits from Ecuador. The results presented here contribute to determining the potential of these tropical fruits as sources of biological compounds beneficial to human health, potentially justifying their consumption as new sources of these types of compounds for human nutrition.

Author Contributions: Conceptualization, M.B. and J.M.A.-S.; methodology, J.M.A.-S., M.B., and F.G.; formal analysis, M.G., E.T., M.G.G.-A., G.I., M.C.-T., S.G.-A., and T.J.-V.; investigation, J.M.A.-S.; resources, J.M.A.-S.; data curation, M.B., F.G., and J.M.A.-S.; writing-original draft preparation, J.M.A.-S. and F.G.; writing-review and editing, M.B.; funding acquisition, J.M.A.-S.

Funding: This study was funded by the Universidad de Las Américas (grant number: VET.JMA.17.05). Access to plant genetic resources was granted by means of the Framework agreement for access to plant genetic resources: MAE-DNB-CM-2017-0072-M-001 between the Environment Ministry, Ecuador and the Universidad de Las Américas.

Conflicts of Interest: The authors declare no conflicts of interest.

\section{References}

1. De la Torre, L.; Muriel, M.; Navarrete, H.; Macía, M.J.; Balslev, H. Enciclopedia de Las Plantas Útiles Del Ecuador; Herbario QCA \& Herbario AAU: Quito, Ecuador; Aarhus, Denmark, 2008; p. 949.

2. Ahn-Jarvis, J.H.; Parihar, A.; Doseff, A.I. Dietary Flavonoids for Immunoregulation and Cancer: Food Design for Targeting Disease. Antioxidants 2019, 8, 202. [CrossRef] [PubMed]

3. Rodríguez-García, C.; Sánchez-Quesada, C.; Gaforio, J.J. Dietary Flavonoids as Cancer Chemopreventive Agents: An Updated Review of Human Studies. Antioxidants 2019, 8, 137. [CrossRef] [PubMed]

4. Slavin, J.L.; Lloyd, B. Health Benefits of Fruits and Vegetables. Adv. Nutr. 2012, 3, 506-516. [CrossRef] [PubMed]

5. Santhakumar, A.B.; Battino, M.; Alvarez-Suarez, J.M. Dietary Polyphenols: Structures, Bioavailability and Protective Effects against Atherosclerosis. Food Chem. Toxicol. 2018, 113, 49-65. [CrossRef] [PubMed] 
6. Li, Y.; Schellhorn, H.E. New Developments and Novel Therapeutic Perspectives for Vitamin C. J. Nutr. 2018, 137, 2171-2184. [CrossRef] [PubMed]

7. Alvarez-Suarez, J.M.; Carrillo-Perdomo, E.; Aller, A.; Giampieri, F.; Gasparrini, M.; González-Pérez, L.; Beltrán-Ayala, P.; Battino, M. Anti-Inflammatory Effect of Capuli Cherry against LPS-Induced Cytotoxic Damage in RAW 264.7 Macrophages. Food Chem. Toxicol. 2017, 102, 46-52. [CrossRef] [PubMed]

8. Zhong, L.; Bornman, J.F.; Wu, G.; Hornoff, A.; Dovi, K.A.P.; Al-Ali, H.; Aslam, N.; Johnson, S.K. The Nutritional and Phytochemical Composition of the Indigenous Australian Pindan Walnut (Terminalia Cunninghamii) Kernels. Plant Foods Hum. Nutr. 2018, 73, 40-46. [CrossRef] [PubMed]

9. Alvarez-Suarez, J.M.; Giampieri, F.; Gasparrini, M.; Mazzoni, L.; Forbes-Hernández, T.Y.; Afrin, S.; Battino, M. Guava (Psidium guajava L. Cv. Red Suprema) Crude Extract Protect Human Dermal Fibroblasts against Cytotoxic Damage Mediated by Oxidative Stress. Plant Foods Hum. Nutr. 2018, 73, 18-24. [CrossRef] [PubMed]

10. Vasco, C.; Ruales, J.; Kamal-Eldin, A. Total Phenolic Compounds and Antioxidant Capacities of Major Fruits from Ecuador. Food Chem. 2008, 111, 816-823. [CrossRef]

11. Vasco, C.; Riihinen, K.; Ruales, J.; Kamal-Eldin, A. Phenolic Compounds in Rosaceae Fruits from Ecuador. J. Agric. Food Chem. 2009, 57, 1204-1212. [CrossRef]

12. Pérez-Balladares, D.; Castañeda-Terán, M.; Granda-Albuja, M.G.; Tejera, E.; Iturralde, G.; Granda-Albuja, S.; Jaramillo-Vivanco, T.; Giampieri, F.; Battino, M.; Alvarez-Suarez, J.M. Chemical Composition and Antioxidant Activity of the Main Fruits, Tubers and Legumes Traditionally Consumed in the Andean Regions of Ecuador as a Source of Health-Promoting Compounds. Plant Foods Hum. Nutr. 2019, 74, 350-357. [CrossRef] [PubMed]

13. Alarcón-Barrera, K.S.; Armijos-Montesinos, D.S.; García-Tenesaca, M.; Iturralde, G.; Jaramilo-Vivanco, T.; Granda-Albuja, M.G.; Giampieri, F.; Alvarez-Suarez, J.M. Wild Andean Blackberry (Rubus glaucus Benth) and Andean Blueberry (Vaccinium floribundum Kunth) from the Highlands of Ecuador: Nutritional Composition and Protective Effect on Human Dermal Fibroblasts against Cytotoxic Oxidative Damage. J. Berry Res. 2018, 8, 223-236. [CrossRef]

14. Giampieri, F.; Gasparrini, M.; Forbes-Hernandez, T.Y.; Mazzoni, L.; Capocasa, F.; Sabbadini, S.; Alvarez-Suarez, J.M.; Afrin, S.; Rosati, C.; Pandolfini, T.; et al. Overexpression of the Anthocyanidin Synthase Gene in Strawberry Enhances Antioxidant Capacity and Cytotoxic Effects on Human Hepatic Cancer Cells. J. Agric. Food Chem. 2018, 66, 581-592. [CrossRef] [PubMed]

15. Singleton, V.L.; Orthofer, R.; Lamuela-Raventós, R.M. Analysis of Total Phenols and Other Oxidation Substrates and Antioxidants by Means of Folin-Ciocalteu Reagent. Methods Enzymol. 1998, 299, 152-178. [CrossRef]

16. Dewanto, V.; Wu, X.; Adom, K.K.; Liu, R.H. Thermal Processing Enhances the Nutritional Value of Tomatoes by Increasing Total Antioxidant Activity. J. Agric. Food Chem. 2002, 50, 3010-3014. [CrossRef] [PubMed]

17. Giusti, M.; Wrolstad, R.E. Characterization and Measurement of Anthocyanins by UV-Visible Spectroscopy. In Handbook of Food Analytical Chemistry; John Wiley \& Sons, Ltd.: Hoboken, NJ, USA, 2005; Volume 2, pp. 19-31.

18. Wang, L.; Fu, H.; Wang, W.; Wang, Y.; Zheng, F.; Ni, H.; Chen, F. Analysis of Reducing Sugars, Organic Acids and Minerals in 15 Cultivars of Jujube (Ziziphus jujuba Mill.) Fruits in China. J. Food Compos. Anal. 2018, 73, 10-16. [CrossRef]

19. Doyon, G.; Gaudreau, G.; St-Gelais, D.; Beaulieu, Y.; Randall, C.J. Simultaneous HPLC Determination of Organic Acids, Sugars and Alcohols. Can. Inst. Food Sci. Technol. J. 2013, 24, 87-94. [CrossRef]

20. Benzie, I.F.F.; Strain, J.J. The Ferric Reducing Ability of Plasma (FRAP) as a Measure of "Antioxidant Power": The FRAP Assay. Anal. Biochem. 1996, 239, 70-76. [CrossRef]

21. Prymont-Przyminska, A.; Zwolinska, A.; Sarniak, A.; Wlodarczyk, A.; Krol, M.; Nowak, M.; de Graft-Johnson, J.; Padula, G.; Bialasiewicz, P.; Markowski, J.; et al. Consumption of Strawberries on a Daily Basis Increases the Non-Urate 2,2-Diphenyl-1-Picryl-Hydrazyl (DPPH) Radical Scavenging Activity of Fasting Plasma in Healthy Subjects. J. Clin. Biochem. Nutr. 2014, 55, 48-55. [CrossRef]

22. Rufino, M.D.S.M.; Alves, R.E.; de Brito, E.S.; Pérez-Jiménez, J.; Saura-Calixto, F.; Mancini-Filho, J. Bioactive Compounds and Antioxidant Capacities of 18 Non-Traditional Tropical Fruits from Brazil. Food Chem. 2010, 121, 996-1002. [CrossRef] 
23. Schiassi, M.C.E.V.; de Souza, V.R.; Lago, A.M.T.; Campos, L.G.; Queiroz, F. Fruits from the Brazilian Cerrado Region: Physico-Chemical Characterization, Bioactive Compounds, Antioxidant Activities, and Sensory Evaluation. Food Chem. 2018, 245, 305-311. [CrossRef] [PubMed]

24. Núcleo de Estudos e Pesquisa em Alimentação (NEPA); Universidade Estadual de Campinas (UNICAMP). Tabela Brasileira de Composicao de Alimentos-TACO 4 Edicao Ampliada e Revisada; UNIVERSIDADE ESTADUAL DE CAMPINAS-UNICAMP: Campinas, Brazil, 2011; p. 164.

25. United States USDA National Nutrient Database for Standard Reference, Release 27 | GHDx. Available online: http://ghdx.healthdata.org/record/united-states-usda-national-nutrient-database-standardreference-release-27 (accessed on 25 February 2019).

26. Almeida, M.M.B.; de Sousa, P.H.M.; Arriaga, Â.M.C.; do Prado, G.M.; Magalhães, C.E.D.C.; Maia, G.A.; de Lemos, T.L.G. Bioactive Compounds and Antioxidant Activity of Fresh Exotic Fruits from Northeastern Brazil. Food Res. Int. 2011, 44, 2155-2159. [CrossRef]

27. United States Department of Agriculture Agricultural Marketing Service Fruit and Vegetable Division Processed Products Branch. United States Standards for Grades of Extracted Honey. Available online: http://onlinebooks.library.upenn.edu/webbin/book/lookupname?key=United\%20States.\%20Agricultural\% 20Marketing\%20Service.\%20Fruit\%20and\%20Vegetable\%20Division (accessed on 20 June 2019).

28. Ramful, D.; Tarnus, E.; Aruoma, O.I.; Bourdon, E.; Bahorun, T. Polyphenol Composition, Vitamin C Content and Antioxidant Capacity of Mauritian Citrus Fruit Pulps. Food Res. Int. 2011, 44, 2088-2099. [CrossRef]

29. Institute of Medicine (US) Panel on Dietary Antioxidants and Related Compounds. Dietary Reference Intakes for Vitamin C, Vitamin E, Selenium, and Carotenoids; National Academies Press (US): Washington, DC, USA, 2000. [CrossRef]

30. Campos, D.; Chirinos, R.; Gálvez Ranilla, L.; Pedreschi, R. Bioactive Potential of Andean Fruits, Seeds, and Tubers. In Advances in Food and Nutrition Research; Academic Press: San Diego, CA, USA, 2018; Volume 84, pp. 287-343.

31. De Souza, V.R.; Pereira, P.A.P.; Queiroz, F.; Borges, S.V.; De Deus Souza Carneiro, J. Determination of Bioactive Compounds, Antioxidant Activity and Chemical Composition of Cerrado Brazilian Fruits. Food Chem. 2012, 134, 381-386. [CrossRef]

32. García-Cruz, L.; Valle-Guadarrama, S.; Salinas-Moreno, Y.; Joaquín-Cruz, E. Physical, Chemical, and Antioxidant Activity Characterization of Pitaya (Stenocereus Pruinosus) Fruits. Plant Foods Hum. Nutr. 2013, 68, 403-410. [CrossRef]

33. Khoo, H.E.; Ismail, A.; Mohd-Esa, N.; Idris, S. Carotenoid Content of Underutilized Tropical Fruits. Plant Foods Hum. Nutr. 2008, 63, 170-175. [CrossRef]

34. Berni, P.; Campoli, S.S.; Negri, T.C.; de Toledo, N.M.V.; Canniatti-Brazaca, S.G. Non-Conventional Tropical Fruits: Characterization, Antioxidant Potential and Carotenoid Bioaccessibility. Plant Foods Hum. Nutr. 2019, 141-148. [CrossRef]

35. Bazalar Pereda, M.S.; Nazareno, M.A.; Viturro, C.I. Nutritional and Antioxidant Properties of Physalis peruviana L. Fruits from the Argentinean Northern Andean Region. Plant Foods Hum. Nutr. 2018, 68-75. [CrossRef]

36. Khayyat, M.; Barati, Z.; Aminifard, M.H.; Samadzadeh, A. Changes in Fruit Maturity Indices and Growth Pattern along the Harvest Season in Seedless Barberry under Different Altitude Conditions. J. Berry Res. 2018, 8, 25-40. [CrossRef]

37. Walker, R.P.; Famiani, F. Organic Acids in Fruits. In Horticultural Reviews; John Wiley \& Sons, Inc.: Hoboken, NJ, USA, 2018; pp. 371-430.

38. Galani, J.H.Y.; Patel, J.S.; Patel, N.J.; Talati, J.G.; Galani, J.H.Y.; Patel, J.S.; Patel, N.J.; Talati, J.G. Storage of Fruits and Vegetables in Refrigerator Increases Their Phenolic Acids but Decreases the Total Phenolics, Anthocyanins and Vitamin C with Subsequent Loss of Their Antioxidant Capacity. Antioxidants 2017, 6, 59. [CrossRef] 
39. Trumbo, P.; Schlicker, S.; Yates, A.A.; Poos, M. Dietary Reference Intakes for Energy, Carbohydrate, Fiber, Fat, Fatty Acids, Cholesterol, Protein and Amino Acids. J. Am. Diet. Assoc. 2002, 102, 1621-1630. [CrossRef]

40. Kosińska-Cagnazzo, A.; Weber, B.; Chablais, R.; Vouillamoz, J.F.; Molnár, B.; Crovadore, J.; Lefort, F.; Andlauer, W. Bioactive Compound Profile and Antioxidant Activity of Fruits from Six Goji Cultivars Cultivated in Switzerland. J. Berry Res. 2017, 7, 43-59. [CrossRef] 